DOI https://doi.org/10.30525/978-9934-588-92-1-25

\title{
ПРАВО НА ТАЕМНИЦЮ КОРЕСПОНДЕНЦІЇ В УМОВАХ ПАНДЕМІЇ КОРОНАВІРУСУ В УКРАЇНІ І СВІТІ
}

\author{
Левченко А. В. \\ аспірантка кафедри конституиійного, \\ адміністративного та кримінального права \\ ДВНЗ «Київський начіональний економічний університет \\ імені Вадима Гетьмана» \\ м. Київ, Украӥна
}

Сьогодні весь світ, в тому числі і Україна, опинилися перед загрозою життю і здоров'ю людей, яка викликана поширенням гострої респіраторної хвороби COVID-19, спричиненої коронавірусом SARS-CoV-2. Кожна країна, враховуючи складність ситуації, вжила певних заходів для мінімізації випадків зараження і захворювання на COVID-19 та зменшення кількості летальних випадків. Уряди одних країн запроваджували режим надзвичайного стану (Чехія, Італія, Іспанія, Румунія, Болгарія, Латвія), уряди інших - режим надзвичайної ситуації (як наприклад в Україні), дехто взагалі не визнав коронавірус пандемією i, незважаючи на заклики Організації об'єднаних націй i Всесвітньої організації охорони здоров'я, так i не запровадив особливих правових режимів для боротьби з хворобою (Білорусь).

Звичайно, будь-який 3 цих особливих правових режимів, чи то надзвичайна ситуація, чи надзвичайний стан, забезпечується шляхом обмеження певних прав і свобод людини. При цьому в таких ситуаціях дуже важлива оцінка дій держави 3 точки зору обгрунтованості i необхідності обмежень прав і свобод людини.

Як в Україні, так і за кордоном, обмеження при надзвичайному стані зазвичай означають тимчасову відмову від гарантій особистої недоторканності і недоторканності житла, обмеження свободи слова, права на проведення страйків, обмеження свободи пересування, обмеження певних економічних прав і свобод, як наприклад свободи приватної власності. Серед переліку особистих прав людини, які уряд може обмежити в умовах надзвичайного стану, $є$ і право на таємницю кореспонденції, що передбачає право на таємницю листування, телефонних розмов, телеграфної та іншої кореспонденції.

Так, у статті 55 Конституції Королівства Іспанії серед усіх прав, які можуть бути припинені в умовах надзвичайного стану, називають $\mathrm{i}$ 108 
право на таємницю листування, в тому числі поштових і телеграфних повідомлень, а також телефонних переговорів. Стаття 19 Конституції Португальської Республіки містить перелік прав, які в жодному разі не можна обмежувати в умовах надзвичайного стану. І оскільки право на таємницю кореспонденції в цьому переліку відсутнє, то відповідно 3 моменту запровадження надзвичайного стану таке право може обмежуватись [1, с. 42].

У березні 2020 року ці країни ввели режими надзвичайних станів у зв'язку з пандемією коронавірусу. Очевидно, що в такому випадку уряд дозволив обмеження певних прав і свобод людей. Зокрема, право на таємницю кореспонденції в умовах боротьби з коронавірусною хворобою в цих країнах лишилось незахищеним і могло зазнавати обмежень.

До того ж, обмеження прав і свобод людини в умовах надзвичайних ситуацій дозволяється i Конвенцією про захист прав людини i основоположних свобод (1950 рік) (далі - Конвенція). Стаття 15 Конвенції зазначає, що під час війни або іншої суспільної небезпеки, яка загрожує життю нації, будь-яка Висока Договірна Сторона може вживати заходів, що відступають від іiї зобов'язань за цією Конвенцією, виключно в тих межах, яких вимагає гострота становища, і за умови, що такі заходи не суперечать іншим іiі зобов'язанням згідно 3 міжнародним правом. Зазначене стосується і зобов'язань щодо захисту права на повагу до приватного і сімейного життя, яке передбачає також і право на таємницю кореспонденції і закріплене в статті 8 Конвенції.

Виходячи із практики Європейського суду з прав людини (далі Суд), зокрема справи «Lawless проти Ірландіï» (1961 рік), щодо порушення таких прав в контексті статті 15 Конвенції, завжди, коли заявник скаржиться на те, що його права за Конвенцією були порушені протягом періоду відступу від зобов'язань, Суд спочатку перевіряє, чи можуть вжиті заходи бути виправданими відповідно до основних статей Конвенції і лише якщо вони не можуть бути виправдані таким чином, Суд переходить до визначення того, чи був відступ від зобов'язань правомірним.

Крім того, Суд в своїх поясненнях щодо застосування статті 15 Конвенції вказував, що належна увага приділяється таким факторам, як: характер прав, що постраждали у зв'язку 3 відступом від зобов'язань, обставини, що призводять до виникнення надзвичайної ситуації, та іiі тривалість. Як приклад можна навести справу Суду «Brannigan та MrBride проти Сполученого Королівства» (1993 рік). Також Суд визначає, чи було б звичайне законодавство достатнім, щоб впоратися із загрозою, що спричинена суспільною небезпекою; чи $\epsilon$ заходи дійсною реакцією на надзвичайну ситуацію; чи були заходи 
використані з тією метою, для якої вони були санкціоновані; чи були передбачені гарантії проти зловживань [2].

Наразі суди конституційної юрисдикції європейських країн вже зіштовхнулися зі справами, в яких йдеться про безпрецедентні обмеження прав та свобод людини в умовах карантинних обмежень. Так, Конституційний Суд Словаччини у травні зупинив дію частини змін до законодавства, якими запроваджувалася передача значної кількості персональних даних від мобільних операторів уряду задля відстежень контактів громадян [3, с. 29]. Дійсно, зазначене демонструє значне обмеження права людини на таємницю іiі кореспонденції.

Важливо відзначити, що обмеження прав і свобод людини в умовах надзвичайного стану можуть вводитись виключно із зазначенням строків дії цих обмежень. Натомість в Україні було введено режим надзвичайної ситуації, який не має законодавчо визначених меж ні щодо строку дії, ні щодо прав, які можуть бути обмежені, ні щодо ступеня їх обмеження.

Згідно зі статтю 64 Конституції України конституційні права i свободи людини i громадянина не можуть бути обмежені, крім випадків, передбачених цією Конституцією. В умовах воєнного та надзвичайного стану можуть встановлюватись окремі обмеження прав $\mathrm{i}$ свобод із зазначенням строку дії цих обмежень. Серед прав, які заборонено обмежувати навіть в умовах надзвичайного стану, відсутнє право на таємницю листування, телефонних розмов, телеграфної та іншої кореспонденції, гарантоване статтею 31 вітчизняної Конституції. Тому безумовно в такій ситуації це право може зазнавати обмежень.

При цьому, всупереч конституційним нормам Постановою Кабінету Міністрів України від 11.03.2020 року № 211 «Про запобігання поширенню на території України гострої респіраторної хвороби COVID-19, спричиненої коронавірусомSARS-CoV-2» та подальшими змінами до неї були введені значні обмеження конституційних прав i свобод. Водночас обговорювалось питання щодо відслідковування переміщень громадян за допомогою мобільних телефонів у рамках боротьби з COVID-19. Зазначалось, що правоохоронні органи мають технічні можливості і зможуть стежити через телефони за місцем перебування потенційних хворих на коронавірус. Однак, як зазначив Міністр внутрішніх справ А. Аваков, це буде прямим порушенням конституційних прав, оскільки в Україні не запроваджено надзвичайний стан [4].

Між іншим, ні Закон України «Про захист населення від інфекційних хвороб», ні Закон України «Про забезпечення санітарного та епідемічного благополуччя населення», якими керувався 110 
український уряд при запровадженні режиму надзвичайної ситуації $\mathrm{i}$ встановленні карантинних обмежень, не можуть наділяти Кабінет Міністрів України повноваженнями обмежувати права і свободи людини. Можливість таких обмежень законна лише у випадку запровадження воєнного чи надзвичайного стану, оголошеного Указом Президента України. Як наслідок - до українських судів вже надходять позови щодо незаконного обмеження прав і свобод людини у зв'язку із введенням на території України карантинних обмежень.

Беручи зазначене до уваги, можна зробити висновок про певні порушення вимог Конституції України запровадженим режимом надзвичайної ситуації і встановленням карантинних обмежень, які $є$ незаконними.

Тому уряд кожної країни повинен обгрунтовано запроваджувати обмеження прав людини в умовах сьогоднішньої боротьби з пандемією коронавірусу, що стосується і права на таємницю кореспонденції. А кожен 3 нас має усвідомлювати особисту відповідальність і з розумінням ставитись до обгрунтованих і законно встановлених запроваджених обмежень.

\section{Література:}

1. Хила І.Ю. Конституційні основи обмеження прав і свобод в умовах надзвичайного стану: досвід зарубіжних країн. Науковий вісник публічного та приватного права. 2019.Випуск 2. Том 1. С. 39-44.

2. Криворот В., Мартиненко А. Втручання в права людини під час пандемії. Юридична газета online. 27 березня 2020. URL: https://yurgazeta.com/publications/practice/inshe/vtruchannya-v-prava-lyudini-pidchas-pandemiyi.html (дата звернення: 09.10.2020).

3. Конституційний процес в Україні: політико-правові аспекти (бюлетень інформаційно-аналітичних матеріалів) / за ред. Л. Дубровіна та ін. Київ: Національна бібліотека України імені В.І. Вернадського, серпень 2020. № 8.63 с.

4. Аваков А.: потенційних хворих на коронавірус зможемо відстежити по телефону. Украӥнська правда. 29 березня 2020. URL:https://www.pravda.com.ua/news/2020/03/29/7245564/ (дата звернення: 09.10.2020). 